\title{
Macro-Modelling, Default and Money ${ }^{1}$
}

\author{
Charles Goodhart \\ Financial Markets Group \\ London School of Economics \\ c.a.goodhart@1se.ac.uk
}

\author{
Nikolaos Romanidis \\ Said Business School \\ University of Oxford \\ Nikolaos.Romanidis@sbs.ox.ac.uk
}

\author{
Dimitrios P. Tsomocos \\ Saïd Business School \\ University of Oxford \\ Dimitrios.Tsomocos@sbs.ox.ac.uk
}

\author{
Martin Shubik \\ Cowles Foundation \\ Yale University \\ martin.shubik@yale.edu
}

\begin{abstract}
Mainstream macro-models have assumed away financial frictions, in particular default. The minimum addition in order to introduce financial intermediaries, money and liquidity into such models is the possibility of default. This, in turn, requires that institutions and price formation mechanisms become a modelled part of the process, a 'playable game'. Financial systems are not static, nor necessarily reverting to an equilibrium, but evolving processes, subject to institutional control mechanisms themselves subject to socio/political development. Process-oriented models of strategic market games can be translated into consistent stochastic models incorporating default and boundary constraints.
\end{abstract}

Keywords: Default; Money; Financial Intermediation; Liquidity; Modelling

Strategies. JEL Categories: A10; C70; D50; E11; E50; G10

\footnotetext{
${ }^{1}$ We would like to thank Vassili Bazinas, Udara Peiris, Xuan Wang, Ji Yan and especially Nuwat Nookhwun for their helpful comments. However, all remaining errors are ours.
} 


\section{Why Mainstream Macro-Modelling is Insufficient}

When the Queen came to the London School of Economics, to open a new academic building, in November, 2008, shortly after the recent financial crisis had struck, she turned to one of her hosts, and asked "Why did no one warn us of this?" One reason for this failure to foresee the coming financial debacle was that mainstream economic models assumed away all such financial frictions. Standard DSGE models were in essence real (Real Business Cycle, RBC) models, with the addition of price/wage stickiness (frictions).

All models involve simplification, and such simplification has both benefits, in enabling focus and a capacity to manipulate and solve, and costs, in the guise of departure from reality. The assumption of no default by any agent, as represented by the transversality condition for example, allowed for much simplification. The whole financial sector could be eliminated from such models; all agents could borrow, or lend, at the same riskless interest rate(s) since there was no credit (counter-party) or liquidity risk; it greatly facilitated the adoption of the 'representative agent' as a modelling device (this also has the incidental property that it rules out any examination of changes in the wealth structure of an economy).

Under normal conditions the treatment of finance as a 'veil', and the assumption that default is constant and low may be a reasonable approximation to reality. But then, in such normal times almost any form of simple modelling, such as a vector auto-regression, will forecast as well as or better than the more complex macro-models. What, however, appears clear from the historical records is that really serious disturbances to the economy, both deflation and depression on the one hand, and inflation on the other, are closely connected to monetary and financial malfunctions. In particular, many of the most severe depressions have been set off by bank defaults and the concomitant collapse of asset prices. Amongst such occasions are 1907, failure of the Knickerbocker Trust; 1929-32, failure of Credit Anstalt and the Bank of New York; 2008, failure of Lehman Bros. The failure, and the expectation of potential failure, of major financial entities have been key drivers of macro-economic weakness throughout modern history.

While the standard DSGE model does not include financial intermediaries, let alone the rare instances of their default, it does normally include (outside) money. Fluctuations in monetary growth, which may be caused in part by financial failure, can, with sticky prices, lead to depression in such 
models when monetary growth is abruptly cut back, and of course to inflation when monetary growth surges.

But the inclusion of money in such a model is itself anomalous and internally inconsistent, as Hahn originally argued in 1965, and as has been repeatedly underlined by the authors here (Quint and Shubik 2013, Goodhart and Tsomocos 2011). If no one ever defaults, anyone's personal IOU will be perfectly acceptable, and perfectly liquid, in purchasing any good, service or other (financial) asset from anyone else. There is no need for any specific money, and devices such as cash in advance constraints, money in the utility function, etc., are not only artificial but internally inconsistent with the other assumptions of the model (see for example Fischer Black 1970 and 1987 and the experimental work of Huber, Shubik and Sunder 2009).

Moreover, the 'no default' assumption of mainstream DSGE models is internally inconsistent in other respects. There is no explicit mechanism in such models to enforce repayment (plus interest). Homo economicus in such models is supposed to be rationally selfish. So if she can default in circumstances when the benefit of so doing (i.e. more consumption) outweighs the cost, she should do so. Yet she is assumed not to do so, an internal inconsistency. In essence if individuals, or institutions, are meant to have any strategic power whatsoever, while lending plays any role whatsoever, bankruptcy and default rules are required as a logical necessity, not just an institutional addition.

The minimum addition to standard macro-models that is necessary to introduce money, liquidity, credit risk, financial intermediaries, (such as banks), and financial frictions in general, (and bank and other agents' failures in particular), is the possibility of default. It has been a major part of the work of the fourth author here to model default, and to show how such default affects the working of the financial system and the economy more widely (Shubik 1973, Shubik and Wilson 1977). It has also been the largest part of our analytical endeavour to extend this work towards the construction, calibration and estimation of macro-models in which default plays a central role, and in which, therefore, monetary and banking developments have real effects, (money and banks are non-neutral). The development of Strategic Market Games (Shubik, 1973 and Shapley and Shubik, 1977) came about in order to turn the essentially static general equilibrium model into a system with fully and properly delineated processes for dynamic adjustment. Money played a critical role in providing the extra degree of freedom that enabled the system to be defined out of equilibrium as well as in equilibrium; but money alone, unless 
in sufficiency and appropriately distributed, did not guarantee efficient market outcomes. Credit had to be introduced. The introduction of credit leads to the need to specify default conditions. Furthermore if through error, intent or chance credit cannot be repaid, the default laws keep the rules of motion well-defined.

Since the original introduction of default into the economic system, there has been a considerable growth in the literature on bankruptcy and default, both in an open or partial equilibrium setting and a closed or general equi-librium setting, as represented by the works of Hellwig, 1981, Dubey, Geanakoplos and Shubik 2005, Zame 1993, Geanakoplos and Zame, 2010 and in a dynamic programming setting Geanakoplos, Karatzas, Shubik and Sudderth 2000.

Our methodological approach may be compared and contrasted with the classical Walras-Arrow-Debreu (W-A-D) general economic equilibrium model and its extension by Lucas. The W-A-D model is essentially non-institutional and static. No institutions are present in this model and the market structure of the economy is ad hoc in the sense that the "invisible hand" brings the system to a resting point. All the real world phenomena that pertain to credit, liquidity, default and financial intermediation are absent from the classical paradigm. In addition, the W-A-D is static and cannot be defined properly out of equilibrium. Through the operation of the invisible hand, one can study the equilibrium properties of the model, provided that one such equilibrium is selected arbitrarily, because the classical model manifests a great degree of indeterminacy. In other words, since there are more unknowns than equations, the equilibrium specification requires additional ad hoc assumptions to be well defined. Thus, the process that leads to an equilibrium outcome is undefined and patently absent from thatis model.

Our methodological approach is not subject to any of the above criticisms. In particular, both the minimal insti-tutions emerge as logical necessities to close our model and the process of adjustment is an integral part of our framework. The degrees of freedom that actually exist, even in the classical model, are so many that institutions have to emerge to generate a determinate solution. Unless one is prepared to make the following implausible assumptions:

- complete financial markets,

- no transactions costs,

- personal complete commitment, (no strategic default),

then money (fiat or commodity) has to be introduced as a means of payment. Money and the associated 
transac-tions technology remove the nominal indeterminacy which the classical W-A-D model (even without uncertainty) manifests. In addition, the transactions technology that we introduce underscores the importance and the real effects of liquidity in the economy and, consequently, of monetary policy. In our approach there exists a genuine interaction of the real and the financial sectors of the economy. The study of monetary policy must be done in a framework where credit, money and liquidity matter. Analysis of monetary policy and, more generally of fiscal and regulatory policy in a non-monetary world is akin to performing surgery on the operating table without the patient being present!

The real world is uncertain, as well as risky; there are unknown unknowns, as well as known unknowns. It is too costly to hedge all eventualities, even when their probabilities may be assessed. When people can get away with not paying their debts, they will do so. So the first step in our analysis is to consider the possibility of default on the contractual obligations that an agent undertakes and, therefore, indicates the necessity for some form of a cash-in-advance constraint. The interplay of liquidity and default justifies (fiat) money as the stipulated mean of exchange. Otherwise, the mere presence of a monetary sector without any possibility of endogenous default or any other friction in equilibrium would become a veil without affecting real trade and, eventually, the final equilibrium allocation. Indeed, cashin-advance constraints are the minimal institutional arrangement to capture a fundamental aspect of liquidity and how it interacts with default to affect the real economy.

The introduction of institutions in our framework and the specific price formation mechanisms that we analyse explicitly require process oriented models that are well defined not only in equilibrium but also out of equilibrium. The class of models that we have produced are all "playable games" in the sense that they can be implemented,

e.g. in a classroom, with clear and well articulated rules of the game. In conclusion, we argue that the introduction of institutions and of financial frictions in an economic model provides for the guidance of the economy as a loosely coupled economic system and acts as its "neural network". The inclusion of default, money, financial institutions, liquidity, etc., allow policy to be explicitly addressed and connect the different players, including differing generations, in a coherent fashion. It is only by constructing a mathematical institutional economics that one can study the economic system in a rigorous and analytical manner.

This should be done. But if it was easy, it would already have been done. It is not easy because in a world with 
default, money and credit risk, there are numerous (evolving) institutions and financial instruments (not just a single (credit riskless) interest rate at which everyone can borrow or lend, (see for example, Woodford 2003). Moreover agents differ in their risk aversion and probability of default; hence there is no room for the 'representative agent' simplification in a satisfactory model. To give a brief illustration of the complexity of the scale of the kind of minimum model, (n.b. it is without housing, fiscal policy, non-bank financial intermediaries, and is a single, closed economy), see Chart 1.

Finally, with missing financial markets, since we depart from the complete markets paradigm, there are important welfare consequences. As Geanakoplos and Polemarchakis (1986) argued, the general equilibrium with incomplete markets model leads to constrained inefficient equilibria. Not only does the first welfare theorem not hold, as it does in the standard W-A-D model, but also the second best is not obtained. The consequence of this is that policy and government intervention may generate welfare improving effects for consumers and firms without necessarily removing the frictions in the short run. Indeed, in Goodhart, Kashyap, Tsomocos and Vardoulakis (2013) we produce one such example whereby multiple regulations Pareto improve the equilibrium allocation.

\subsection{Chart 1}




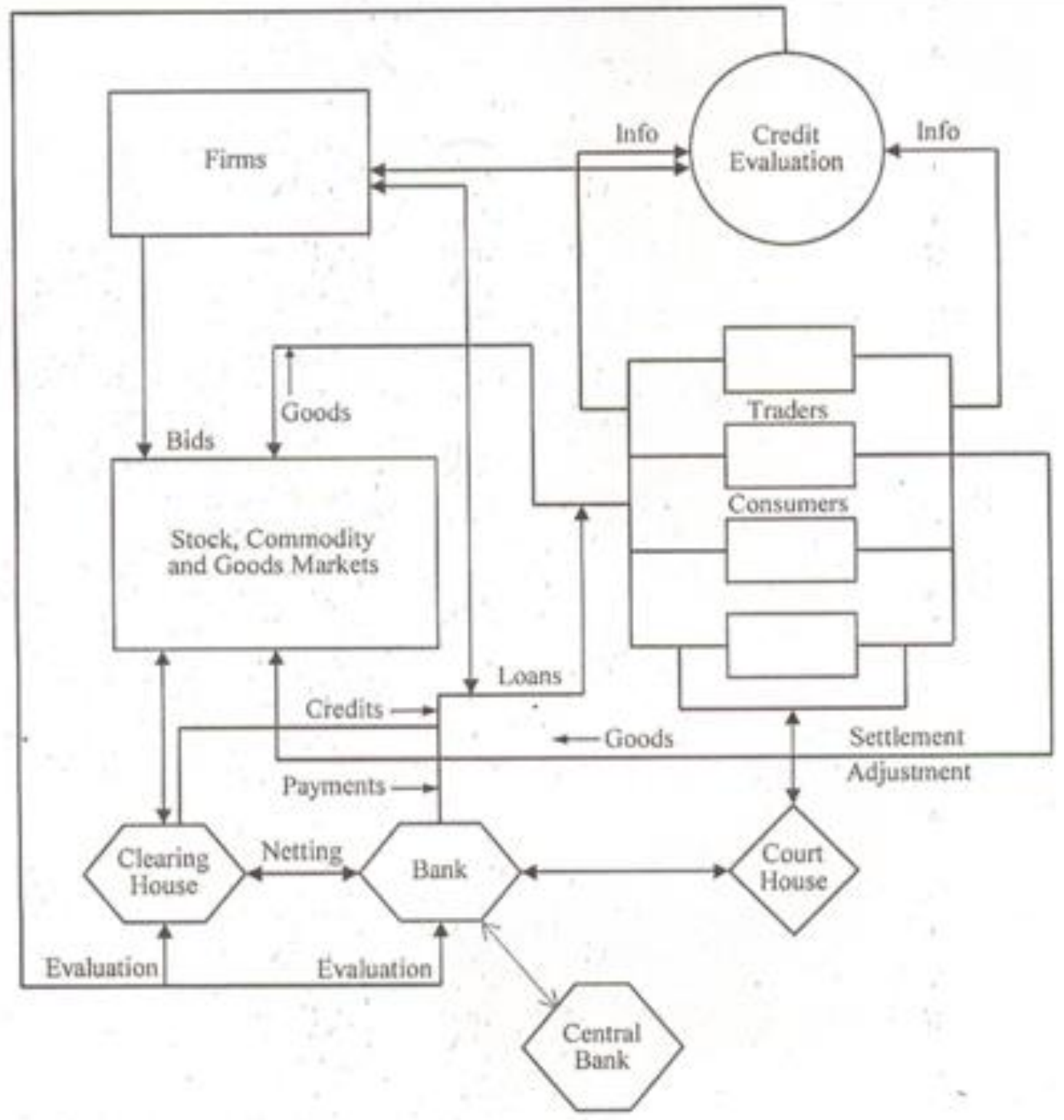

2 Source of Frictions in General Equilibrium models 
In this section, we discuss the-some sources of financial frictions and the way that these frictions have been are introduced in dynamic models. The list of the models is by no means exhaustive ${ }_{2}$ but indicative at best $_{2}$ so as to present some the-common financial frictions that have been considered in the literature.

The interaction between credit constraints and the aggregate economy over the business cycle was studied by Kiyotaki and Moore (1997). Credit limits are endogenously determined. Their presence generates large and persistent fluctuations in output and asset prices, in the face of a relatively small, unexpected shock.

Durable assets play a dual role: they are factors of production and they serve as collateral for loans. Moreover, borrowers' credit limits are affected by the price of collateral but these prices are contemporaneously affected by the size of the credit limits. Hence, this interaction between credit limits and asset prices constitutes the transmission mechanism through which shocks persist, amplify and spread out. In sum, the main friction in this paper is the credit constaint that arises because lenders cannot force borrowers to repay their debts without the loans being collateralised.

Agency costs were introduced by Bernanke and Gertler (1989) and used by Carlstrom and Fuerst (1997) whereby they extend an otherwise standard real business cycle model by introducing endogenous agency costs. The agency problem arises from the information asymmetry between the capital-producing entrepreneur (who is in need of funds) and the mutual fund (which helps intermediate savings from households). Agency costs are thus imposed on the creation of new capital. The paper adopts the costly state verification argument-mechanism of Townsend (1997) in the design of a the-financial contract, leading borrowers to pay a higher cost for external finance, which is in turn influenced by the level of their net worth. The simulation produces a hump-shaped response of output to an aggregate productivity shock. The evolution of net worth plays an important role in contributing to such dynamics.

These agency issues are introduced by assuming that the capital investment risk level is privately observed by the entrepreneur whereas others can privately observe only the capital investment risk 
level after meeting at - a monitoring cost. This asymmetry thus creates a moral hazard problem. The entrepreneur will default if the capital investment risk is low and the lender will monitor the project outcome only if the entrepreneur defaults, in which case he will confiscate all the returns from the project.

Eventually, the contract is completely defined by the pair of loan amount and the cutoff level of capital investment risk where the entrepreneur defaults. The optimal contract is given by the pair that maximises the entrepreneur's expected return subject to the lender being indifferent between lending the funds and retaining them. Bernanke, Gertler and Gilchrist (1999) use agency costs to establish the external finance premium that generates the financial accelerator. They develop a dynamic stochastic general equilibrium (DSGE) model that clarifies the role of credit market frictions in business fluctuations from both a qualitative and a quantitative point of view. Curdia and Woodford (2009) present an extension of the basic Neo-Keynesian model of the monetary transmission mechanism to allow for a spread between the interest rate available to savers and borrowers that can vary for either exogenous or endogenous reasons. Thus, the friction in this model, is the spread between the borrowing and the lending rate so that to capture financial stability aspects of monetary policy.

Gertler and Kiyotaki (2010) introduce an agency problem between banks and their lenders, assuming that banks can abscond away-with part of their assets and so lending is restricted so that they do not do so in equilibrium. The novel ingredient in their model is the existence of an interbank market, where the trade exists due to an idiosyncratic liquidity shock, and-where the an agency problem also occurs. The model simulations suggest that an adverse the-shock to the quality of bank assets has a serious adverse-effect on banks's loan supply of funds and, hence, the real economy. The authors also assess the impact of credit market intervention.

A second generation of models has attempted to address financial stability issues within a DSGE framework and assess regulatory policies. Iacoviello and Neri (2010) built a DSGE model with a housing market and borrowing constraints while including several shocks and frictions for empirical purposes. They attempt to first identify shocks that drive the housing market and, second, how fluctuations in the 
housing market propagate to other forms of expenditure. On the supply side, they add sectoral heterogeneity, meaning that the non-housing sector produces consumption and business investment using capital and labor, and the housing sector produces new houses using capital, labor, land and intermediate inputs. On the demand side, housing and consumption enter households' utility and housing can be used as collateral for loans. Since housing and consumption goods are produced using different technologies, the model generates heterogeneous dynamics both in relation to business investment and in the price of housing. Meanwhile, fluctuations in house prices affect the borrowing capacity of a fraction of households, on the one hand, and the relative profitability of producing houses, on the other, implying that these mechanisms generate feedback effects for the expenditure of households and firms. In a similar vein, Christiano, Motto and Rostagno (2010) expand a standard monetary Neo-Keynesian DSGE model to include financial markets and a friction due to the liquidity constraint that the-banks face.

Collateral constraints a la Kiyotaki and Moore (1997) have been exploited in another strand of recent research which emphasizes occasionally binding constraints, e.g., in Bianchi and Mendoza (2010). It can be analytically shown that overborrowing occurs in normal times (when the constraint does not bind) compared to the social planner equilibrium, due to the agents' failure to internalize the effect of collective asset fire sales on their prices during a crisis. Such overborrowing increases the likelihood of the credit constraint becoming binding in the face of negative income shocks, and, consequently, raises the probability and depth of the financial crisis. Those papers highlight the need of macro-prudential measures that generate incentives for precautionary savings.

Meh and Moran (2010) are-building a DSGE model where bank capital mitigates the agency problem between banks and their creditors. Consequently, the capital position of banks affects their ability to attract loanable funds and therefore influences the business cycle.

Fostel and Geanakoplos (2008) offer a theory how leverage cycles can cause contagion, flight to collateral and issuance rationing. The frictions in this model are basically, the existence both of include collateral and a liquidity wedges which basically isrespresent the excess interest that an agent would be willing to promise in a state to get a loan if he did not have to put up any collateral, but was 
indeed committed to fully repaying. The leverage cycle- is the driving force that causes the liquidity wedge cycle and affects asset prices and hence the collateral value. This ${ }_{2}$ in turn in periods of distress, enhances the negative effects of the business cycle.

Finally, there exists a class of models where default is genuinely endogenous and regulations are assessed in a fully general equilibrium framework. Goodhart, kKashyap, Tsomocos and Vardoulakis $(2012,2013)$ explore how different types of financial regulation could combat many of the phenomena that were observed in the financial crisis of 2007 to 2009. Their proposed framework can assess five different policy options that officials have advocated for combating default, credit crunches and fire sales, namely: limits on loan to value ratios, capital requirements for banks, liquidity coverage ratios for banks, dynamic loan loss provisioning for banks, and margin requirements on repurchase agreements used by shadow banks.

\section{Modelling a Macro-economic System with Default}

The possibility of default amongst economic agents, companies, and above all, financial institutions is not only pervasive, but also at discrete moments can have a dominating impact on macro-economic developments. Trying to air-brush default out of macro-economic models will mean that they are at best partial, and at worst, as in recent years since 2007, almost completely useless. But, unfortunately, the attempt to incorporate default as a central, key component of such models makes their construction far more difficult.

In particular, it makes the dimensionality of the model so much larger. It is no longer feasible to use the useful fiction of a representative agent. Not only do agents, in practice, vary in risk aversion, (and such risk aversion may vary over time in response to events), but also if all agents were required to move in lockstep as a representative agent then either none default (so the model reverts to the default free form) or they all simultaneously default, which may lead to the collapse of the model.

Next, the number of sectors in the model will increase. With default, there is a two-fold function for banks. On the liability side, bank deposits, especially when insured, are less subject to default (a lower PD) than the IOUs of (most) other members of the private sector, and hence become used as acceptable 
means of payment. On the asset side banks should have a comparative advantage in assessing the creditworthiness of other agents' IOUs (borrowing proposals) and monitoring them to insure that PD is kept lower ${ }^{2}$. Likewise with incomplete financial markets, and asymmetric information, there is room for a large assortment of other financial intermediaries.

In the standard DSGE model there are two assets, (though as argued above, one of these, i.e. outside money, zero interest-bearing currency, is actually redundant and should play no role). The other, main asset in the model is riskless debt, which all agents can issue for borrowing, or buy for saving. In equilibrium, when the system finishes, all borrowers in the final period just have enough income to pay off their entire debt with certainty; and all net savers just obtain sufficient repayment in that final session to finance their planned expenditures. Hence there is no residual availability of funds, or equity finance in such models.

By contrast, once default is allowed to occur, a much wider menu of financial assets naturally occurs, including currency, bank deposits and bank loans, debt with a wide range of credit ratings, as well as a whole range of derivatives, other intermediary liabilities and assets, and equity. In other words it is default that gives a meaning, and an explanation, for the wide assortment of financial assets/liabilities that we observe in practice. Put this all together, and this means that a model, with default at its centre, will have more agents per sector, more sectors and more assets. The problem immediately arises of a potentially exploding dimensionality, (besides the additional complexity of maximising subject to bankruptcy costs). This can be, and has been, partially resolved by refocusing the model in each case to deal with a specific issue, and omitting those agents/sectors/assets not strictly necessary for the question at hand. But this means that models with default have not yet been 'general' in the sense of encompassing a complete macro-economy for all questions. Yet good application calls for ad hoc models of specific economies designed to answer relevant questions with a general theoretical basis that can be applied to the case at hand.

A main challenge is still how to extend such general models with default, such as Shubik (1999), Dubey and Geanakoplos (2003), Tsomocos (2003), Dubey, Geanakoplos and Shubik (2005) and Goodhart, Sunirand and Tsomocos (2006), in a dynamic setting, preserving the main properties of a

2 After those occasions when (some) banks fail in function 2, and hence amass non-performing loans (npls) and then fail (or approach failure), there is usually a call to split these two functions, into a narrow bank which provides payments services on retail deposits against safe (government) assets on the one hand, and a lending institution financed by some other (non-payment) set of liabilities on the other. The general idea is to increase safety, even at the expense of efficiency. The arguments, pro and con, are perennial and outside the scope of this paper. 
parsimonious model, without the inclusion of redundant or unrealistic features. The initial endeavours, by Leao (2006), de Walque (2010) and Iacoviello (2005), that introduced those concepts into the DSGE framework, have not taken into account simultaneously liquidity, agent heterogeneity, money and default risk. Nevertheless, those models are valuable efforts in the development of a plausible explanation of the phenomena observed after the credit crisis. The interplay of liquidity and de- fault justifies the presence of fiat money as the stipulated medium of exchange. Otherwise, the mere presence of a monetary sector without the possibility of endogenous default or any other friction in equilibrium may become a veil without affecting real trade and, eventually, the final equilibrium allocation. Indeed, liquidity constraints, or their extreme version of cash-in-advance constraints, are the minimal institutional arrangement to capture a fundamental aspect of liquidity and how it interacts with default to affect the real economy. It is also worth noting that renegotiation is a first cousin of default. Renegotiation is often used euphemistically to tell the public that no default has taken place.

There is, perhaps, an even more fundamental problem with models with default. Such default can happen at any time, from the interaction of stochastic events with agents' risk aversion. Thus there is no sense in which such models can ever settle down into some long-run unchanging equilibrium. Indeed, the underlying problem is even worse. Laws, market structures, and economic institutions are themselves subject to endogenous change as a result of experience, witness the changes to financial regulation as a consequence of the recent crisis. Most of us find it difficult to countenance a system which does not revert to an equilibrium, supported by some set of fixed social, legal and institutional structures. Yet the reality of default and crises actually means that we, and the macro-economy, are in the middle of process. A reading of Keynes suggests that he was talking about an economy tending towards equilibrium; not one that actually attained the misleading equilibrium system imposed by Hicks. If one were to add in this context the amendments of Schumpeter on innovation, the appropriate picture at best is one of a system that may follow some adjustment to a perceived equilibrium, but it will be constantly knocked off course by every innovation.

\section{Some Implications of Default as a Process}

\subsection{What are the costs of default?}


One, rather obvious, reason why default has not been made a central feature of macro-economic finance, is that it is quite hard to do. Default is a binary condition. Either an entity has declared bankruptcy, or not. It is, therefore, difficult to fit into the standard models of continuous variables, manipulated and solved via calculus. This problem can be treated by turning it around and focusing not on the occasion of default but on the expectation of repayment, (Shubik, 1999, Ch 12). This is akin to the inverse of the combination of the probability of default (PD) and expected loss given default (LGD) that play such a central role in finance.

If the costs of default were infinite (e.g. death for the debtor and her family), no one would ever borrow. If the costs of default were zero, no one would ever repay, and so no one would ever lend. So, given a positive marginal efficiency of investment and inter-temporal preferences over consumption, an interior optimum must exist with positive, but not infinite, costs of default and positive borrowing and lending. Another problem of modelling default is that its costs depend on institutional conditions and social norms which can change over time, and can, indeed, vary in response to economic conditions, such as the frequency and severity of prior defaults.

There are two main categories of default costs. The first is that the borrower may be required to put the ownership claim to some asset, which may be, but need not always be, the same asset bought with the borrowed money, in forfeit to the lender, should the borrower not meet her contractual repayment obligations. This is known as the collateral for the loan, and loans protected by such collateral are termed secured loans. Normally the market value of the collateral exceeds the value of the loan, with the difference being the required margin, or down payment, that the borrower has to make to get the initial loan. Geanakoplos (2003), and Shubik and Yao (1990), have focused primarily on this aspect of the cost of default.

Naturally the required margin will be greater, the greater is the perceived risk of the collateralised asset falling (volatility) and the greater the deviation between the value of the asset to the lender, should foreclosure occur, and to the borrower, e.g. houses during a housing price collapse. Thus this aspect of the borrower/lender relationship, the extent of down payment, margin or leverage available is highly cyclical, with the costs of borrowing (margins, down-payments) going up sharply during financial crises and busts, and going down during expansionary booms. Since there is no need for collateral in a world 
without default, this aspect of the cost of borrowing is omitted from standard DSGE models without financial frictions.

Monetary policy aims to stabilise the macro-economy by lowering (raising) riskless interest rates during depressions (booms), but, without having a better grasp of the impact on borrowing/lending decisions of the changing terms and conditions of borrowing, which generally fluctuate inversely to interest rates, it is impossible to forecast at all accurately what the net effect on private sector behaviour may be. Particularly after a financial crisis, policies which focus solely on official rates without concern with spreads and margins facing private sector borrowers are likely to be inefficient and insufficient. The difficulty of assessing the changing effects of terms of borrowing is one reason why focusing on quantities of lending or monetary growth may be often a better indicator of the effects of monetary policy, than is looking at the time path of some chosen interest rate.

Besides having to give up (to the lender) such collateral as the borrower may have pledged, or can be seized by the lender, e.g. in the case of sovereign default, there are other costs to default. These depend, inter alia, on the form of the bankruptcy laws, (see La Porta, Shleifer et al. 2000 for a useful overview). Some such costs can be non-pecuniary, e.g. debtor's prison, social shame, loss of use of asset (house, car, etc.); some may be pecuniary, e.g. the present value of future exclusion from financial markets, legal costs, the reduction in income as the bankrupt has to shift from her preferred role and occupation to a less-preferred activity.

Modelling both the time-varying collateral (margin/down-payment) costs and the more direct costs of bankruptcy is an under-developed aspect of macro-economics, and one that needs much more attention. In much of our own work to date we have assumed that the direct costs of bankruptcy were fixed in linear proportion to the rate of repayment failure ${ }^{3}$ (Shubik 1999 Ch11, Qin and Shubik 2010), but more analytical and empirical work would be useful to try to explore this key element in the model. Further in our work with Kashyap and Vardoulakis we have begun to examine the effects of changing margins and collateral on the financial system.

\subsection{DSGE Models and Default}

\footnotetext{
${ }^{3}$ The parameter may be regarded as an approximation for the marginal disutility of default. A more general functional form would ad little to the qualitative understanding, but is mathematically considerably more complex.
} 
Default in these models (Bernanke, Gertler and Gilchrist (1999), Carlstrom and Fuerst (1997) and Christiano, Motto and Rostagno (2010)) and their variants occurs, however in an naïve way. It is implicitly assumed that a fraction of entrepreneurs goes bankrupt and this probability of bankruptcy is treated like-as an parameter. However, the model is capable to-can endogenise this probability_- using the an optimal financial contract. There is - can be both ex ante and ex post default, operating at the firm level. Some of the firms do default in equilibrium, as their return to capital is subject to both idiosyncratic and aggregate risk. However, in aggregate, the bank is assumed to be able to diversify its loan portfolio, so that it repays depositors the riskless rate of interest. The -Such idiosyncratic risk can affect the firm's equity is -through the cost channel, since expected default probability directly relates to affects the interest rate paid by firms. Default in their model is not genuinely endogenous. Banks and firms do not choose explicitly what amount to default upon. However, the firm chooses its capital demand and cutoff productivity level where the firm will start to default in order to maximize its expected profits subject to a bank's participation constraint. Hence, by optimally raising the cutoff level, it subjects itself to a higher probability that it will default in the case that the realized productivity level turns out to be low. It may $_{2}$ or may not ${ }_{2}$ default in the end, given the realization of the shock. As it turns out, there is no default in equilibrium in the financial sector. Banks charge a default premium to borrowers so that on average they break even!

Curdia and Woodford (2009) and Meh and Moran (2010) address default in a completely ad hoc fashion. In the former impatient households default on their loans every period by an exogenous amount that is known to the banks. In the latter, in each period, a fraction of the (risk-neutral) entrepreneurs and a fraction of (risk-neutral) bankers exit the economy and they are replaced by new ones with zero assets. The aforementioned fractions are exogenously given. Moreover, even entrepreneurs and bankers associated with successful projects might receive a signal to exit the economy.

De Walque et al (2009) introduces endogenous default probabilities for both firms and banks ${ }^{4}$. Following Goodhart et al (2006), the borrowers optimally choose the rate of repayment of loans, taking into account penalties incurred. The penalties can be both non-pecuniary in terms of reputation cost, and pecuniary in

\footnotetext{
${ }^{4}$ Martinez and Tsomocos (2016) produce a related model that studies the interplay between liquidity and default.
} 
terms ofte-search costs to obtain new loans. Financial friction arises as lenders price in such default probability into the interest rates, and in line with previous literature, contributes to the financial accelerator. Their model is then used to assess the role of capital regulations and liquidity injections on economic and financial stability. In response to the current crisis, where disruption in financial intermediation generates negative consequences on the real economy, some recent articles have shifted focus to impose credit constraints on intermediaries, rather than on non-financial borrowers.

The rest of the-Most other models, despite their focus on default, they-do not generate any bank default in equilibrium.

\subsection{The need for money}

My, or your, IOU will, in general, not be acceptable as payment for a trade because the counterparty will not know the probability of our repaying the debt, and it would be too expensive (in time and effort) to find out. In principle, however, if all probability distributions were (costlessly) common knowledge, (no Knightian uncertainty) and financial markets were complete (all outcomes could be hedged), then, even in the presence of default, anyone's personal IOU would be perfectly acceptable in exchange, so once again money, as such, would not exist. But the existence of unknown unknowns, and transactions costs, makes the concept of complete financial markets fictional.

In the real world people will offer, and buyers will accept, in payment for trade the IOU of an agent whose credit- worthiness is greatest. In most cases this is the IOU of the local sovereign power. In international trade the IOU of the most powerful country will tend to become the vehicle currency (currently the US\$). Of course there may be times when the power structure has broken down, or when the two sides to the trade come from different socio- political systems (e.g. early colonialists trading with indigenous natives). In such cases there may be a need for reversion to barter. But barter is an extremely expensive form of transaction. Not only does it divert the barter good from its alternative use, but it also involves, sometimes considerable, search costs in identifying the precise quality of the goods being offered.

Sometimes social custom enabled exchange to occur in response to payment by number of items without regard to their precise individual quality. Thus cattle vary idiosyncratically in quality, but were 
frequently used in more primitive societies as payment, e.g. the bride price. Although cattle hardly have the qualifications to be a useable means of payment (not easily inventoried, portable or divisible), nevertheless their use in payment in early societies was so common that the word, pecuniary, derives from the Latin word for cattle. This, along with gold, silver and cocoa beans illustrate the early close linkages between a means of payment and store of value in systems with rudimentary laws.

The use of pure, raw, metal in payment is also subject to transaction costs. Metals are of differing purity and weight. Before accepting gold dust, or a silver bar in payment, the seller would need to have the metal assayed and weighed. An answer to this was to develop mints where the sovereign could place a stamp on the coin as a guarantee of a certain quality. So long as the sovereign would accept the coin back as payment for taxes, the stamp itself, rather than the metallic value of the coin, helped to determine its value in exchange. The more powerful, and permanent, was the sovereign power, the closer the coins came to IOUs rather than barter goods. Seignorage provided a substantial income (Shubik and Tsomocos 2002). 


\subsection{The functions of liquidity}

In the absence of default, it is hard to give much meaning to the concept of liquidity. Markets may be thin, with quite wide bid-ask spreads, large price impacts and with little resilience. But each agent can borrow, at the given riskless rate of interest, up to a limit given by her need to repay with certainty, and is presumed not even to try to borrow beyond that limit. So, up to that limit each agent is fully liquid, and can buy whatever she wants. Up to that limit no agent is liquidity constrained. The implicit assumption of mainstream DSGE is that, in equilibrium, no agent is liquidity constrained, i.e. that no agent is attempting to borrow so much that it has a non-zero probability of default. This also removes any significant distinction between long and short term loans, and treats accounting and evaluation as free goods.

If agents are perceived as likely to default, then they will only be able to borrow at rising interest rates, or not at all (credit rationing). If so, their ability to spend will be constrained by their access to income and owned liquid assets. In this latter case agents are liquidity constrained.

In equilibrium, the scale of economic activity, the volume of goods and services traded in a period, is endogenous. By contrast, in the model of Lucas and his followers the scale of economic activity is exogenously specified by the requirement that each agent sells the whole of his endowment in each period. A corollary of the quantity theory of money in a model with default, ceteris paribus, is that increases in trading activity in a good state, due perhaps to more productivity or lower interest rates, will result in lower price levels, given the same money supply in that state. Similarly, the volume of trade in asset markets affects prices and has second order effects on the inflation rate.

\subsection{Non-neutrality of money}

Given the existence of money, then government monetary policy (open market operations, i.e. changing the stock of bank money) necessarily has real effects on consumption. Similarly, government transfers of money to agents, no matter how it is distributed across the population, also necessarily has real effects. These non-neutrality conclusions are contrary to those derived by Lucas. The explanation is that in a model with default, equilibrium is not Pareto efficient, because of the distortion caused by trading via money borrowed at positive interest rates. When the government eases credit (by putting 
more money into the banks, e.g. by open market operations) it facilitates borrowing, reduces interest rates, and increases real activity. In an $\mathrm{RBC}$ model with wage/price frictions, the mainstream DSGE models, money is non-neutral in the short run, but becomes neutral in the long run as the wage/price frictions dissipate. Financial frictions provide another, and probably rather longer-lived source of non- neutrality. Financial developments, and monetary policy, will help to determine timevarying perceptions of the probability of default, and hence risk spreads and the liquidity constraints of agents. The present euro-crisis can be analysed in the context of models in which default is possible. It cannot be adequately analysed by using models without default. It has been the ubiquity of the latter kind of model that has led Central Bank heads, such as Trichet and King, to complain that macroeconomics provides no guide to the present dire conjunction.

There is also another deeper sense in which finance is non-neutral. In RBC models growth is driven by an exogenous (trend) increase in productivity, deriving from innovations, which is disturbed in the short run by a variety of shocks. In models with default, growth and fluctuations in growth will also be driven by the willingness, and ability, of agents to assume risk. Virtually all projects, especially innovative projects, are risky. So a very risk averse society is likely to be safe, but slow growing. Levine has documented the positive association between financial intermediation and growth. But the rapid expansion of credit expansion, and leverage can put the economy at greater risk, as evidenced since 2000 (Taylor 2009).

Society, and governments, can change the costs of default, and the costs and availability of access to borrowing (e.g. via intermediaries) by a variety of regulatory measures. What we should be trying to assess is the optimal structure of (regulatory) control over risk, by such instruments as Recovery and Resolution Programmes (RRPs), capital adequacy requirements (CARs), margin requirements, etc., to give the best balance between growth (more risk taking) and financial disturbances (less risk taking). Models without default cannot even begin to address this issue; models with default at their heart can now begin to do so (Goodhart, et al, 2013). Indeed, one notable feature of the exercises to reform and to improve financial regulation in recent decades, e.g. Basel I, II and III, is how little they have been informed by macro-economic theory (Goodhart 2011, Chapter 16), at least until quite recently. This lacuna was, at least in part, owing to the implicit belief amongst macro-economists that such matters had no, or little, macro-economic effects. In a world without default such a view would have been 
correct; but that world does not exist in practice.

\subsection{The unification of macro-economics, micro-economics and finance}

In recent decades the models and the focus of attention of macro-economists, micro-economists and financial theorists have drifted apart. In so far as such macro-economic models abstract from default, their sole focus on financial matters was on the determination of the official, short-term, interest rate, usually via a Taylor reaction function, and thence on the determination of the riskless yield curve, via expectations of the future path of official rates. So, such macro-economists had little interest in financial intermediation, which played no role in their models.

In contrast, of course, the probability of default played a major role in finance theory and in the pricing of as- sets. Even here, however, the existence and incidence of bankruptcy costs was often assumed away, as in the Modigliani-Miller theorem, or their wider impact on the economy, via externalities, ignored. In a different sphere the mathematical micro-economists and game theorists, as noted above, have written extensively on bankruptcy in a general equilibrium or strategic market game setting but with little connection to macro-economic literature, although one might regard the work of Diamond and Dybvig 1983, Morris and Shin 2004 and Smith and Shubik 2012 on bank runs as connected with macro-economic stability.

Be that as it may, a greater appreciation, especially amongst macro-economists, of the importance of financial frictions in general, and of default in particular, is likely to re-unify these specialisations. The, often physical, separation of micro-, and macro-economists in Economics Departments and of finance theorists in Business Schools with almost entirely differing agenda and models has not been beneficial. The greater focus now on financial frictions as a key issue in money-macro analysis will have the side-advantage of reunifying these three strands of the subject, which should never have been allowed to diverge as far as they did.

Also note that the bankruptcy process, like innovation, does not involve the destruction of real assets. It involves their reorganization. The only items that are destroyed are credit arrangements. One of the deepest misunderstanding of the public, in general, is the fear of the myth of a bankruptcy process. The public appears to believe that it is the assets that are destroyed, whereas in fact a well-executed 
bankruptcy may be the savior of on-going enterprises ${ }^{3}$. The recent-saving of General Motors from bankruptcy in the United States in the Great Financial Crisis, for example is presented as an act that saved over a million jobs (including many of the upper management of General Motors), though it is debatable whether an orderly bankruptcy of General Motors with a subsequent take over by a group led by, say, Toyota or Honda might have been better for all concerned other than the continuing G.M. management.

\section{Modelling Banks: An example of how, and how not, to undertake financial modelling}

The failure to focus on financial frictions was partly responsible for a continuing, often egregious, failure in most macro work to model the behaviour of financial intermediaries, especially banks. If such intermediaries were part of a veil, with no real effect, why bother?

Even amongst those who most emphasised behavioural incentives and optimisation, the supply of money was often, and in most textbooks until recently, supposedly controlled by a deterministic, and tautological, formula, the monetary base multiplier, whereby the stock of money depended on the stock of base money and two ratios, the banks' desired reserve/deposit ratio and the public's desired currency/deposit ratio. Causation supposedly ran from the monetary base, supposedly set by the Central Bank, to the broader money supply. This formula provided the analytical framework for the (otherwise) great historical book by Friedman and Schwartz.

One of the most difficult blocks to understanding is the half-truth that can easily be mistaken simplistically for the whole. The two reserve ratios in banking, like the quantity theory of money, illustrate simplistic truths in a highly over-simplified world that is worth looking at by the theorists using them as benchmarks from whence to measure reality, not as reality itself.

Even in the decades, prior to the 1970s, which had conditions most appropriate to this formulation with required cash, and sometimes required liquidity, ratios, the monetary base multiplier was upside

\footnotetext{
${ }^{3}$ The renegotiation of sovereign debt can be an euphemism for a less transparent and efficient process than a clean reorganization by bankruptcy
} 
down. As everyone, including prominently Milton Friedman, knew in practice, the policy choice variable of (almost all) Central Banks, almost all the time, was the level of the official short-term interest rate. Given that official interest rate, and other macro conditions (and their risk aversion), banks would decide on their own interest rate terms and conditions for lending (and for offering interest-bearing deposits), with such decisions in turn often dependent on various controls applied by the authorities. That determined credit and monetary expansion, while the banks' and public's preferences for reserves and currency then determining the monetary base that the authorities had to create in order to maintain their separately decided policy choice over short-term interest rates ${ }^{4}$.

The concept that the commercial banks were cash, or liquidity, constrained became even sillier after the 1970s. The emergence of the euro-dollar market in the late 1960s and early 1970s, and its extension into an international wholesale market for funds, meant that all credit-worthy banks, which meant most large banks most of the time, could raise large amounts of additional funding whenever they wanted on standard terms on such markets, e.g. the elasticity of supply of such wholesale funds to any one bank was high; banks were price takers in wholesale markets.

Funding liquidity was replacing market (asset) liquidity. At least, prior to the 1970s, when a bank treasurer was contemplating credit expansion, he had to consider how such loans might be funded. Once the wholesale markets got going, all the treasurer needed to compare was the expected risk-adjusted rate of return on credit expansion with the marginal interest rate on wholesale markets. Prior to the 1970s the money stock (broad money) and bank lending marched in lock-step together. After the 1970s they increasingly diverged, with credit expansion growing far faster than broad money (Schularick and Taylor, 2012). Bank deposits had, increasingly, been insured after the Great Depression of 1929-33, in order to prevent runs; the new wholesale funding of credit expansion, via MMFs, Repos, etc., was not, but no one paid that much attention, since the credit-worthiness of bank borrowers in such markets was meant to be anchored by their adherence to the Basel Capital Adequacy Ratios (CARs).

So where and how is this, perfectly well known, history of banking and financial developments reflected in a modern theory of banking and money (and near-money) supply determination. The blunt answer is that, by and large, it is not. One can, indeed, say that there is at present no theoretical analysis of

\footnotetext{
${ }^{4}$ Technically when three are no constraints, control of the quantity of money or control of the rate of interest by the Central Bank give the same results as they are dual variables. This is not so when there are constraints present.
} 
banking worthy of the name. This has unfortunate consequences. At the start of the unconventional monetary expansions, after the zero-lower bound to interest rates was hit, (QE, CE, LTROs, etc.), it was widely hoped that expansion of the monetary base $(\mathrm{H})$ would lead to some large scale, if not fully commensurate, expansion in broad money and bank lending. It did not. In most key developed countries the monetary base tripledquadrupled; bank lending and broad money barely budged. Besides some general arm-waving about a lack of demand for credit from the private sector, there has been a dearth of post-mortems, of analyses about why the banks behaved as they did.

Then in pursuit of the closure of stable doors, from which the horses had already bolted, the authorities, especially in Europe, mandated the early achievement of sharply higher ratios of equity to (riskweighted) assets. But what factors would determine bank willingness to raise additional equity? Admati (and Hellwig) have shown that, especially where there is debt overhang and a perceived risk of insolvency, the benefits of additional equity go largely to the creditors, not to existing shareholders. So existing shareholders, and bank managers responsive to their shareholders, will eschew all, and any, methods of reinforcing equity, by new issues or profit retention, as far as possible. That implies that raising required equity ratios will be achieved by deleveraging. Of course, each country's monetary authorities will try to ensure that such deleveraging will not take the form of reductions in bank lending to the private sector by their own banks in their own countries. So cross-border bank lending gets decimated, (actually decimation was only one out of ten; this is in many cases nearer nine out of ten), and so-called 'non-core' assets are forcibly sold. This has led to the balkanisation and fragmentation of the European banking system.

Meanwhile most analytic studies of the effects of regulation on banking demonstrated that, in equilibrium, a banking system with a higher equity ratio would not require any much higher interest charge on bank lending, and would be much safer. All this is perfectly true. The problem has been that the present banking system is not in an equilibrium state but is in a transitional process under conditions of severe market stress. It has long been a key theme of ours, that the focus on equilibrium conditions in mainstream macro is insufficient, and even at times potentially misleading. What needs to be done instead is to model financial developments as a continuing process. Rarely has this argument been so clearly manifested as in the case of banking in the aftermath of the 2008 debacle.

In a series of excellent symposia reported in the Journal of Economic Perspectives there has been an 
attempt to look back at the debacle in 2008. In particular Gorton 2010 and Gorton and Metrick 2011 trace the explosion of leveraging by the sophisticated utilization of instruments such as the Repo. Note that the utilization of the Repo is recorded by Bagehot 1873 in an appendix in his masterful work, Lombard Street.

Those who study finance deal with the micro-economic realities of the arbitrage among markets, laws, customs, accounting conventions and cultures. They also deal with the hi-tech micro-micro-economic problems of mechanism design (see, as a nice example, Caccioli, Bouchaud and Farmer, 2012), and with sophisticated studies in stochastic processes, which seek out even minor fleeting correlations in stock or foreign currency trading in some instances in order to trigger computerized trading. This work rarely interacts with either main stream micro- or macro- economics yet it is relevant to both in the sense that in its devotion to the understanding and profiting from trading, it attempts to capture, at least in the short run, actual financial dynamics, not analogy.

\subsection{Role and Rationale of Financial Sector in General Equilibrium models}

In this section, we present the role and rationale of the financial sector in some general equilibrium models.

In Kiyotaki and Moore (1997), Fostel and Geanakoplos (2008) and Iacoviello and Neri (2010) the financial sector is not modelled. The first model is a pure real model with two types of agents (credit constrained and non-credit constrained) and the non-credit constrained agents directly lend to the credit constrained ones. Thus, in this model there is no financial sector. And the second subsumes the role of the financial sector in the activities of agents, whereas in the last the banking sector is also not present. Likewise, in Bianchi and Mendoza (2010) there is not a fully-fledged financial sector.

The Neo Keynesian models (e.g., Bernanke, Gertler and Gilchrist (1999), Curdia and Woodford (2009)) introduce a rudimentary financial sector to intermediate between the borrowers and savers, thus-introducing a spread between deposit and lending rates. Moreover, state-contingent contracts are introduced between the households in order to insure one another against both aggregate risk and the idiosyncratic risk associated with households types. Banks break even in equilibrium by charging an insurance premium. As a result, aggregate risk is fully absorbed by the entrepreneurial sector. Banks 
are naive as their only role is to intermediate funds in a rather mechanical fashion. For example, in Carlstrom and Fuerst (1997) the entrepreneurs are involved in producing the investment good, receiving their external financing from households via intermediaries that are referred to as capital mutual funds. The production of capital is subject to an idiosyncratic productivity shock and these capital goods are purchased at the end of the period with their-the assistance of intermediaries.

Notable exceptions to this family of models are Christiano, Motto and Rostagno (2010) and Meh and Moran (2010). In Christiano, Motto and Rostagno (2010), there is are-a fully integrated financial sector and competitive banks. They receive deposits from the households and make loans to the entrepreneurs as in Bernanke, Gertler and Gilchrist (1999) and working capital loans to the intermediate good firms and other banks as in Christiano, Eichenbaum and Evans (2005). Banks bundle transactions services with their deposit liabilities and produce transactions services with capital, labor and bank reserves. They hold a minimum of cash reserves against households deposits, consisting of base money and Central Bank liquidity injections. The modeling of the banking sector becomes non-trivial ${ }_{2}$ partially due to the production function for banks deposits or liquidity creation. In particular, capital, labor and excess reserves are utilized. This gives rise to a liquidity constraint for banks, and hence allows certain types of shocks, such as funding liquidity and shocks-shifts in to-demand for excess reserves.

A snapshot of the bank's consolidated balance sheet at the end of time t, a minute before the end of the time- $\mathrm{t}$ production period is structured as follows:

\begin{tabular}{|l|l|}
\hline Infra-Period Assets & Infra-Period Liabilities \\
\hline - Reserves, $A_{t}$ & - Household deposits, $D_{t}^{\prime \prime}=A_{t}$ \\
\hline - Working Capital loans, $S_{t}^{w}$ & - Firm deposits, $D_{t}^{\prime}=S_{t}^{w}$ \\
\hline Inter-temporal Assets & Inter-temporal Liabilities \\
\hline Entrepreneurial loans, $E_{t}$ & - Short-term marketable securities, $D_{t}^{m}$ \\
\hline & - Other financial securities, $T_{t-1}$ \\
\hline
\end{tabular}

In addition there is also a Central Bank that sets the nominal interest rate according to generalized Taylor Rule.

Meh and Moran (2010) extend a similar the basic framework introduced by to-Bernanke, Gertler and Gilchrist (1999). Loans are modeled in a similar fashion. However, the an agency problem is intreduced-posited between the banks depositors and the banking sector. Monitoring is costly and 
depositors cannot monitor the quality of entrepreneurs' projects. Since losses are mostly suffered by depositors, banks lack the incentive to monitor entrepreneurs. Therefore, investors require banks to invest their own capital as well. As a result, banks that are better capitalized attract more loanable funds.

Finally, in Goodhart, Kashyap, Tsomocos and Vardoulakis (2012), there is also a fully integrated banking system with a non-trivial role and furthermore a shadow banking system that during bad times triggers fire sales which further worsen the financial crises by causing further reduction in asset prices. Commercial Banks are risk-averse, take deposits, make mortgage loans, short-term loans to households and repo loans to the shadow banks. They also receive money from the Central Bank through a discount window. Moreover, they securitize mortgage loans and sell them and they are endowed with capital. On the other hand, Shadow Bank are less risk-averse, endowed with capital, receive repo loans to buy securitized assets and use these assets as a collateral for the repo loan. All of them are profit maximizers.

\section{Can such a Complex System ever be Adequately Modelled within a General Equilibrium (GE) Framework?}

Many (mathematical) economists, approaching macro-dynamics from an (industrial) microeconomics viewpoint, have worried about the large number of degrees of freedom that seem to appear as soon as one tries to introduce default and money into a general equilibrium structure. As is often the case, a paradox is no paradox when examined from the appropriate stance. Following any attempt to describe the general equilibrium structure as a playable game with a monetary economy, the immediate critique is that not only is it unduly special but also that the construction could have been done in an astronomically large number of ways. We provide a framework, however, whereby we use institutions as minimally necessary to define the economic process and allow policy experiments to be conducted. Therefore, our analysis is robust to alternative institutional arrangements, since our emphasis is not so much on the specific institutions that we introduce but rather on the externalities that we try to rectify given the frictions that are present in our models. For example, cash in advance formulation is the simplest possible way to capture the effects of liquidity in a transactions based model. Alternatively, we could utilise more complicated liquidity requirements, as in Espinoza and Tsomocos (2010), where not 
only fiat money but also commodities can be partly used for transactions purposes. So this criticism is completely correct, but yet completely misses the positive message, which is the need for a link between static economics on one side and economic dynamics and biology on the other side. The plethora of degrees of freedom are there so that it is feasible to construct hosts of ad hoc micro-macroeconomic models that fit special niches and are able to adjust with varying flexibility to the macro and the macro dynamics to which they are applied. In other words, given each particular friction and its associated externality, we are able to address it in multiple ways without necessarily modifying our results. We consider the fact that we offer many alternatives to address a particular externality a strength rather than a weakness of our approach. One should be aware of all the possible alternatives and subsequently select the one that fits current objectives best. In attempting to describe the general equilibrium structure as a playable game with a monetary economy the immediate critique of anyone who constructs a playable strategic market game is that not merely is it so special but that the construction could have been done in an astronomically large number of ways.

In a modern economy one of the most important markets, albeit usually highly oligopolistic, is the market for the firm, and firms are institutions with both an aggregation of assets and an organization. A good industry specialist trying to forecast the dynamics of the firm and its viability will investigate real and financial assets and liabilities. as well as management and software. A check-list includes:

1. Labor,

2. Land,

3. Buildings

4. Machinery,

5. Raw materials

6. Goods in process

7. Office supplies

8. Cash and receivables

9. Short term debt

10. Long term debt and 


\section{1. financial assets}

12. Software, and off-balance sheet assets such as derivatives and

\section{Management.}

Each of these items may have a time profile attached to it involving properties such as the ages and length of service of management and the age structure of machinery.

Cautious accounting calls for leaving the valuation of management and organization off the balance sheets; but one of the key tasks of a good analyst is to attach estimates to the worth of this off balance sheet asset ${ }^{5}$.

In general the larger institutions are all run by committees of fiduciaries using "Other Peoples' Money" (OPM) and buried in a Byzantine mixture of tax laws, regulation and accounting conventions that place considerable constraints on the manifestation of economic behavior. This observation is not a counsel of despair. It merely suggests that the diversity of time lags and organizational constraints, (that are the daily concern of a good industrial organization economist and any competent financial analyst doing due diligence), do not disappear into the magic wand of a one aggregate single dimension dynamic programming model in any operational sense. Economic dynamics is highly dependent on models aggregated from the bottom up. This is not an impossible, but it is an arduous task. A government in general and a central bank in particular, require empirical evidence on the macro-economy far beyond the analogies of RBC. The challenges and the dangers of bridging the gap between theory and practice were eloquently noted in Edgeworth's inaugural address in 1891 (Edgeworth, 1891). He commented:

- "It is worth while to consider why the path of applied economics is so slippery; and how it is possible to combine an enthusiastic admiration of theory with the coldest hesitation in practice. The explanation may be partially given in the words of a distinguished logician who has well and quaintly said, that if a malign spirit sought to annihilate to whole fabric of useful knowledge with the least effort and change, it would by no means be necessary that he should abrogate the laws of

\footnotetext{
${ }^{5}$ Given this listing, a little contemplation of the description in these terms of a bank, a life insurance company, a family restaurant, an automobile rental firm, a large oil company, a hedge fund or a funeral parlor immediately calls for a taxonomy of dynamic models at least as diverse as an optimal kingdom stretching from whales to ants or mites.

The sizes in terms of both personnel and assets, the flexibility of the institution and their complexity differ so considerably that it is unlikely that "one shoe fits all" when one is trying to develop economic dynamics. This is not counter to general economic theory. It merely places two sets of empirical constraints on it. It implicitly suggests that the understanding of the dynamics of a specific firm in the steel industry requires that one knows considerable physical and financial facts about both the firm and its industry. Yet that alone is not sufficient to describe the dynamics.
} 
nature. The links of the chain of causation need not be corroded. Like effects shall still follow like causes; only like causes shall no longer occur in collocation. Every case is to be singular; every species, like the fabled Phoenix, to be unique. Now most of our practical problems have this character of singularity; every burning question is a Phoenix in the sense of being sui generis." — F.Y. Edgeworth, 1891

In spite of the many successful applications of mathematics to equilibrium economics, the development of economics as a science has a considerable way to go. In particular, as is well known, there is no generally acceptable theory of dynamics. Yet the whole basis of macroeconomics requires economic dynamics.

In the broad sweep of the development of both pure and applied economics, techniques come and go, and fashions change. It has been fashionable for microeconomic theorists to view macroeconomics as ad hoc and "unscientific," while macroeconomists return the compliment by branding topics such as general equilibrium (GE) theory as irrelevant.

This warning by Edgeworth is not an admission of defeat but a call for us to appreciate that the use of dynamics requires an understanding of structure and a realisation that control in a loosely coupled dynamic system is not the same as prediction but the intelligent placement of constraints to prevent an unpredictable dynamics from getting out of control.

In other words, the manifold degrees of freedom in a modern economy require an intelligent appreciation of the missing institutional and/or political constraints that anchor the political economy of modern societal organisations. In addition, these institutions permit comparative institutional dynamics and remove the indeterminacy that follows from the classical W-A-D model and its non-institutional structure. To sum up, we can build a political economy that can be flexible enough to survive robustness checks and yet also be analytically tractable.

Recently one of the authors, with colleagues, has been considering the problems involved in incorporating innovation into a financial control structure. Only two out of four projected papers have been completed (Shubik and Sudderth 2011 and 2012). Even in highly simplified low dimensional models a clean proof of the convergence of a low dimensional dynamic programming mode is difficult to obtain and the length of time to equilibrium may be of any length, however some simulation results show extreme 
instability with the introduction of a banking system (Miller and Shubik 1994).

So, in comparison with the standard dynamic stochastic general equilibrium models, models which face up to the reality of default will surely be dynamic, will generally be stochastic, but can only approach generality and do not converge to an equilibrium. Going down this road has some severe disadvantages. For those who find abandoning both the $G$ and the E features of their familiar DSGE models too much of a stretch, we would suggest that the best way forward is that suggested by Curdia and Woodford (2009), which is to add an ad hoc, exogenous, but time-varying credit-risk spread to the official interest and then proceed as before. It is a simple addition, and incorporates some of the effects of financial frictions (in an ad hoc manner) into the model.

But it does not incorporate all such effects, being unable, for example, to account for the changing terms and conditions of borrowing, notably the cyclical path of collateral, margins and leverage, emphasized by Geanakoplos and Fostel (2008) Also it fails to account for the, sometimes self-amplifying, interactions between the financial system and the rest of the economy; thus weakness in, say, the housing sector can weaken the banks, and their fragility can impinge back onto the economy (and onto government finance) and so on. Finally, taking financial frictions as exogenously given provides no help, or guidance whatsoever, for the monetary authorities in their role as guardians of financial stability. By and large economic theory has played little, or no, role to date in informing the design of financial regulation (Goodhart 2011). One of the key functions that Tsomocos and Goodhart have seen for such models is to provide a top-down approach for assessing stresses in financial markets and in helping to design regulatory reform. Our hope is that Central Banks will come to use such models on a regular basis, besides or instead of models which assume away default, financial intermediation and money, just those variables which should lie at the centre of their concerns.

One of the consequences of the recent financial crisis was the rehabilitation of the reputation of Hy Minsky. He had great insight into the workings of the financial system, but he never formalised these into a model which could be developed as a basis for analysis and for regulatory reform. Our own aim is not to revert only to a narrative and historical approach towards finance, but to extend rigorous and mathematical modeling to encompass a wider set of real and behavioural phenomena.

\section{Where do we go from here?}

We start from the premise that financial systems and markets are not static (with reversion to some 
equilibrium) but evolving processes, subject to institutional control mechanisms which are themselves subject to socio/political development.

The concept of Mathematical Institutional Economics as an appropriate way to develop the dynamics of a financially controlled economy is consistent with Edgeworth's warning, with precise question formulation and an empirically based construction of ad hoc models dealing with the important specific goals of government regulation of an economy with a high level of functionally useful decentralized market activity. The flexible, but logically consistent and complete, process-oriented models of strategic market games translate, with care, into stochastic process models incorporating default and boundary constraints. In special simple examples, it is possibly to obtain interior solutions and even more rarely analytical solutions, but, in general, even the parsimonious models require approximation or simulation methods to trace the dynamics. But because there is no royal road, this does not mean that there is no road.

\section{References}

[1] A. Admati, P. DeMarzo, M. Hellwig, and P. Pfleiderer, (2010), 'Fallacies, irrelevant facts, and myths in the discussion of capital regulation: Why bank equity is not expensive', Rock Center for Corporate Governance at Stanford University Working Paper No. 86.

[2] W. Bagehot, (1873/1999), Lombard Street: A Description of the Money Market, (originally published 1873, New York: Scribner, Armstrong; republished 1999, John Wiley \& Sons).

[3] Bernanke, Ben S., Mark Gertler, and Simon Gilchrist. "The financial accelerator in a quantitative business cycle framework." Handbook of macroeconomics 1 (1999): 1341-1393.

[4] Bianchi, Javier, and Enrique G. Mendoza. Overborrowing, Financial Crises and'Macro-prudential'Taxes. No. w16091. National Bureau of Economic Research, 2010.

[5] F. Black, (1970), 'Banking and interest rates in a world without money: The effects of uncontrolled banking', Journal of Bank Research 1 (Autumn): 8-20. Reprinted as Ch. 1 in Black (1987).

[6] F. Black, (1987), Business Cycles and Equilibrium, (Cambridge, Mass., Basil Blackwell). 
[7] F. Caccioli, J.P. Bouchard and J.D. Farmer, (2012), 'Impact-adjusted valuation and the criticality of leverage', Risk, December.

[8] Charles Carlstrom and Timothy Fuerst (1997). Agency Costs, Net Worth, and Business Fluctuations: A Com- putable General Equilibrium Analysis. American Economic Review, American Economic Association, vol. 87(5), pages 893-910, December.

[9] Christiano, Lawrence J., Martin Eichenbaum, and Charles L. Evans. "Nominal rigidities and the dynamic effects of a shock to monetary policy." Journal of political Economy 113.1 (2005): 1-45.

[10] Christiano, Lawrence J., Roberto Motto, and Massimo Rostagno. "Financial factors in economic fluctuations." (2010). ECB Working Paper Series No. 1192.

[11] V. Curdia and M. Woodford, (2009), 'Credit frictions and optimal monetary policy', Bank of International Settlements Working Paper 278, March.

[12] G. DeWalque, O. Pierrard, and A. Rouabah, (2010), 'Financial (in)stability, supervision and liquidity injections: A dynamic general equilibrium approach’ Economic Journal, 120(549):1234-1261.

[13] D.W. Diamond and P.H. Dybvig, (1983), 'Bank runs, deposit insurance, and liquidity', Journal of Political Economy, 401-419.

[14] P. Dubey and J. Geanakoplos, (2005), The value of money in a finite horizon economy: A role for banks. Economic Analysis of Market and Games, MIT Press, Cambridge, pages 407-444.

[15] P. Dubey and J. Geanakoplos, (2003), 'Monetary equilibrium with missing markets', Journal of Mathematical Economics,39(5):585-618.

[16] P. Dubey, J. Geanakoplos, and M. Shubik (2005), 'Default and punishment in general equilibrium', Economet- rica,73(1):1-37,2005.

[17] R. Espinoza and D.P. Tsomocos, (2010), 'Liquidity and Asset Prices in Monetary Equilibrium', Oxford Financial Research Centre, Financial Economics paper, 28, University of Oxford, Said Business School. 
[18] A. Fostel and J. Geanakoplos, (2008), 'Leverage Cycles and the Anxious Economy', American Economic Review, 98(4):1211-1244.

[19] J. Geanakoplos, (2003), 'Liquidity, default, and crashes endogenous contracts in general', in Advances in Economics and Econometrics: Theory and Applications: Eighth World Congress, page 170.

. [20] J. Geanakoplos, (2010), 'The leverage cycle' NBER Macroeconomics Annual,24(1):1-66, 2010.1.

[21] J. Geanakoplos, I. Karatzas, M. Shubik, and W. Sudderth, (2000), 'A strategic market game with active bankruptcy', Journal of Mathematical Economics,34(3):359-396.

[22] J. Geanakoplos and H.M. Polemarchakis, (1986), 'Existence, regularity and constrained suboptimality of com- petitive allocations when the asset market is incomplete. Uncertainty, Information and Communication': Essays in Honor of KJ Arrow, 3:65-96.

[23] J. Geanakoplos and W. Zame, (2009), 'Collateralized security markets', Unpublished Manuscript. Earlier ver- sions 1997, 2002, 2005.

[24] Gertler, Mark, and Nobuhiro Kiyotaki. "Financial intermediation and credit policy in business cycle analysis." Handbook of monetary economics 3.3 (2010): 547-599.

[25] C.A.E. Goodhart, (2011), The Basel Committee on Banking Supervision: A History of the Early Years, 1974- 1997, Cambridge University Press.

[26] C.A.E. Goodhart, A.K. Kashyap, D.P. Tsomocos, and A.P. Vardoulakis, (2012), 'Financial regulation in general equilibrium'., NBER WP17909.

[27] Goodhart, C. A., Kashyap, A. K., Tsomocos, D. P., \& Vardoulakis, A. P. (2013). An integrated framework for analyzing multiple financial regulations. International Journal of Central Banking, 9(1), 109-143.

[28] C.A.E. Goodhart, M.U. Peiris, D.P. Tsomocos, and A.P. Vardoulakis, (2010), 'On dividend restrictions and the collapse of the interbank market', Annals of Finance, 6(4):455-473.

[29] C.A.E. Goodhart, P. Sunirand, and D.P. Tsomocos, (2006), 'A model to analyse financial fragility', Economic Theory, 27(1):107-142.

[30] C.A.E. Goodhart and D.P. Tsomocos, (2011), 'The role of default in macroeconomics', IMES Discussion Paper Series. 
[31] C.A.E. Goodhart, D.P. Tsomocos, and A.P. Vardoulakis, (2011), 'Modeling a housing and mortgage crisis' Central Banking, Analysis, and Economic Policies Book Series, 15:215-253.

[32] G. Gorton and A. Metrick, (2011), 'Securitized banking and the run on repo', Journal of Financial Economics.

[33] G.B. Gorton, (2010), 'Slapped by the Invisible Hand: The Panic of 2007',. Oxford University Press, USA.

[34] F.H. Hahn, (1965), 'On some problems of proving the existence of an equilibrium in a monetary economy' The Theory of Interest Rates, pages 126-135.

[35] M.F. Hellwig, (1981), 'Bankruptcy, limited liability, and the Modigliani-Miller theorem' American Economic Review, pages 155-170.

[36] J. Huber, M. Shubik, and S. Sunder, (2009), 'Default penalty as a disciplinary and selection mechanism in presence of multiple equilibria', Cowles Foundation Discussion Paper.

[37] Matteo Iacoviello and Stefano Neri (2010). Housing Market Spillovers: Evidence from an Estimated DSGE Model. American Economic Journal: Macroeconomics 2, 125-164.

[38] Nobuhiro Kiyotaki and John Moore (1997). Credit Cycles. Journal of Political Economy, Vol. 105, No. 2.

[39] R. La Porta, F. López de Silanes, A. Shleifer, and R.W. Vishny, (2000), 'Investor Protection and Corporate Governance'. Journal of Financial Economics 58 (1-2): 3-27 [32] E.R. Leao and P.R. Leao, (2006), 'Techno- logical innovations and the interest rate' Journal of Economics, 89(2):129163.

[40] J.F. Martinez and D. P. Tsomocos, (2016), "Liquidity and Default in an Exchange Economy.", Journal of Financial Stability (forthcoming).

[41] C. A. Meh and K. Moran (2010). The Role of Bank Capital in the Propagation of Shocks. Journal of Economic \& Dynamic Control 34 (2010), 555-576.

[42] H.H. Miller and M. Shubik, (1994), 'Some dynamics of a strategic market game with a large number of agents' Journal of Economics, 60(1):1-28. 
[43] S. Morris and H.S. Shin, (2004), 'Liquidity black holes', Review of Finance, 8(1):1-18.

[44] T. Quint and M. Shubik, (2004), 'Gold, Fiat and Credit. An Elementary Discussion of Commodity Money, Fiat Money and Credit', Cowles Foundation Discussion Paper No. 1460.

[45] M. Schularick and A.M. Taylor, (2012), 'Credit booms gone bust: Monetary policy, leverage cycles, and financial crises, 1870-2008', American Economic Review, 102(2):1029-1061.

[46] L. Shapley and M. Shubik, (1977), 'Trade using one commodity as a means of payment', Journal of Political Economy, 937-968.

[47] M. Shubik, (1973), 'Commodity money, oligopoly, credit and bankruptcy in a general equilibrium model', Economic Inquiry, 11(1):24-38.

[48] M. Shubik, (1999), Political economy, oligopoly and experimental games, volume 1 (Edward Elgar Publishing).

[49] M. Shubik and W. Sudderth, (2011), 'Cost Innovation: Schumpeter and Equilibrium. Part 1: Robinson Crusoe', Cowles Foundation Discussion Paper No. 1786, March.

[50] M. Shubik and W. Sudderth, (2012), 'Cost innovation: Schumpeter and equilibrium; part 2: Innovation and the money supply', Cowles Foundation Discussion Paper No. 1881.

[51] M. Shubik and D.P. Tsomocos, (2002), ‘A strategic market game with seigniorage costs of fiat money’ Economic Theory, 19(1):187-201.

[52] M. Shubik and C. Wilson, (1977), 'The optimal bankruptcy rule in a trading economy using fiat money', Journal of Economics, 37(3):337-354.

[53] M. Shubik and S. Yao, (1990), 'The transactions cost of money (a strategic market game analysis)', Mathematical Social Sciences, 20(2):99-114.

[54] J.B. Taylor, (2009), Getting Off Track, (Harper Press).

[55] D.P. Tsomocos, (2003), 'Equilibrium analysis, banking and financial instability' Journal of Mathematical Economics, 39(5):619-655. 
[56] M. Woodford, (2003), Interest and prices: Foundations of a theory of monetary policy (Princeton University Press),

[57] W.R. Zame, (1993), 'Efficiency and the role of default when security markets are incomplete', American Economic Review, 1142-1164. 